\title{
Impact of Global Financial Crisis on FDI Flows in India - A Special Reference to Housing sector
}

\author{
T.Mamata
}

\begin{abstract}
In India after agriculture, the real estate sector is the second largest industry and it is asserted to be the most promising sector even today. The real estate market in India mostly continues to remain unorganized, fairly fragmented, mostly characterized by small players with local presence. Indian real estate has huge potential demand in almost every sector especially commercial, residential, retail, and industrial, hospitality, healthcare etc. More emphasis was laid on FDIs in real estate only from 2005. Secondary data has been used for the study. The trends of the FDI's in real estate sector are compared with the other sectors in India. The FDI inflow data from 2002-2010 has been considered. This data is used to assess the impact of FDI's in India and economic growth achieved through FDI flows. This paper aims at analyzing the flow of FDIs in real estate sector in India and the impact of the global recession on the FDI flows along with the RBI initiations for attracting more FDIs into the real estate sector. It is observed that FDI inflows into several sectors into India are devoid of the declining GDP growth rate which includes the Housing sector also. The impact of recession is averted by the Government intervention, and certain efforts in Housing have in fact helped the economy grow and vice versa.
\end{abstract}

Index Terms-Foreign Direct Investment, economic growth, Real estate sector, global recession on FDI's.

\section{INTRODUCTION}

\section{FDIs in Housing}

In the present global scenario, India has been considered as the most promising and fast growing economy in the world. Due to the liberalized rules for Foreign Direct Investment (FDI's), in India the real estate has been the attractive investment proposal for both the domestic as well as foreign investors and which has enhanced the economy of the country. Foreign direct investment (FDI's) in India's booming real estate and housing market jumped 80 times between 2005 and 2010.Figures show that in 2005, FDIs in real estate was a mere Rs 171 crores. That soared to Rs 13,586 crores in 2009-10. In April and May this year, Rs 737 crores in FDIs were pumped into the sector.

India has been witnessing more money being pumped into housing sector from abroad despite the recent downturn. Since 2005, foreign direct investment (FDIs) worth Rs 37,986 crore has come into the housing sector in India,

T.Mamata, Assistant Professor, Padala Rami Reddi Colleges, Manchirevula, Narsingi, Hyderabad/ Research scholar (JNTU) under the guidance of (Dr.D.Pradeep Kumar, Professor \&Head, Department of Management studies, Madanapalle Institute of Technology and Science, Madanapalle, Andhra Pradesh) including Rs 13,586 crores already this year. It is no surprise that the largest number of building projects where FDIs is in play are in the country's commercial capital, Mumbai. Of the total 1,614 projects in which foreign investors have put in money since 2005, 422 were cleared by the Reserve Bank of India's Mumbai office, followed closely by 316 in Delhi. Other big cities like Bangalore (225 projects), Hyderabad (105 projects) and Chennai (68 projects) also enjoyed considerable attention of foreign real estate developers.

At present, the government allows FDIs in real estate, but does not permit foreign institutional investment. It is, however, considering a proposal not to view FDIs and FII as distinct investment flows while specifying an overall limit. It is yet to permit foreign venture capital investors (FVCI) in the realty sector. To ensure that the concept of special economic zones (SEZs) did not distort the realty market, the RBI has classified lending to SEZs on par with commercial real estate, according it higher risk weight and provisioning. India in the next five-year period is estimated to require investments worth US \$ 25 billion with the urban housing sector. This again has opened up opportunities for foreign investments in the realty sector. The Central government allowed up to $100 \%$ FDIs for setting up townships in 2002 . However, the flow of FDI's investments has been thwarted by the 100 acre criterion; since acquiring such a large chunk of land was impossible in metropolitan cities and even satellite cities and state capitals.

\section{A. Advantages of FDIs in India Real Estate:}

1) FDIs flows in India can encourage and organize the realty sector and thereby also create better employment opportunities in this sector.

2) Technology advancement is possible in construction activity in India whether commercial or residential housing.

3) to create a healthy and competitive market environment for both Indian and foreign investors

4) Better infrastructural facilities are possible with investments from foreign investors.

5) Efficiency in funds management in India and enrich the quality standards for housing sector in India.

\section{Disadvantages of FDIs}

1) There a necessity to frame strategies for better utilization of FDI's inflows as is pressurizes the Indian economy

2) There is also a scope of losing the ownership and entity with the foreign investors in the business.

3) The increased liquidity and consequent inflation due to excessive FDI's inflow in India 


\section{B. FDI Rules (Housing)}

1) The Government of India has set up certain guidelines for investors willing to apply in FDIs in real estate, which has conditions like area, investment options and target for completion of a project

1) Minimum area

In case of development of serviced housing plots, 10 hectares (25 acres).In case of construction-development projects, built-up area of $50,000 \mathrm{sq}$ m.In case of a combination project, any of the above two conditions

\section{2) Investment}

Minimum capitalization For wholly owned subsidiaries US\$ 10 million. For JV with Indian partners - US\$ 5 million-, to be brought in within 6 months of commencement of business. Original investment cannot be repatriated before a period of three years from completion of capitalization. The investor may exit earlier with prior approval from Foreign Investment Promotion Board (FIPB).

\section{3) Time frame \& rules}

At least 50 per cent of the project to be developed within five years from the date of obtaining all statutory clearances. Investor cannot sell undeveloped plots - where roads, water supply, street lighting, drainage, sewerage and other conveniences are not available.

\section{Guidelines for Foreign Direct Investment}

No foreign investment is permitted in this sector except for development of integrated townships and settlements where FDIs upto $100 \%$ is permitted with prior Government approval. NRIs/OCBs are allowed to invest in the following activities.

1) Development of serviced plots and construction of built up residential premises.

2) Investment in real estate covering construction of residential and commercial premises including business centers and offices.

3) Development of townships.

4) City and regional level urban infrastructure facilities, including both roads and bridges.
5) Investment in manufacture of building materials, which is also opened to FDI's.

6) Investment in participatory ventures in (a) to (e) above.

7) Investment in housing finance institutions, which is also opened to FDI's as an NBFC.

The government has also imposed a lock-in period of three years for repatriation of investments made in this sector after the minimum capitalization requirements are complete. Also, 50 per cent of the project must be completed in five years from the date of statutory clearances and the investor is not permitted to sell undeveloped plots.

Some of the foreign players who have already tied up with Indian real estate developers are Lee Kim Tah Holdings, CESMA International Pvt Ltd., Evan Lim, and Keppel Land from Singapore, Salim Group from Indonesia, Edaw Ltd., from USA, Emaar Group from Dubai, IJM, Ho Hup Construction Co., from Malaysia etc.

\section{Methodology}

The study is conducted with the following objectives

1) To analyze the flows of FDI's in Housing Sector before global financial crisis and till date.

2) To study the reasons of Consistency in FDI's during Global Financial Crisis Period.

3) To analyze the Performance and Profitability of FDI's in India for housing sector in comparisons with the other sectors.

4) To study the impact of FDI's on economic Growth in India.

For the study only secondary data has been used. The trends of the FDI's in real estate sector are compared with the other sectors in India. The data from 2002-2010 has been considered. This data is used to assess the impact of FDI's in India and economic growth achieved through FDI's flows.

TABLE 1: HOUSING AND REAL ESTATE FDI'S IN INDIA (2005-2010SEP)

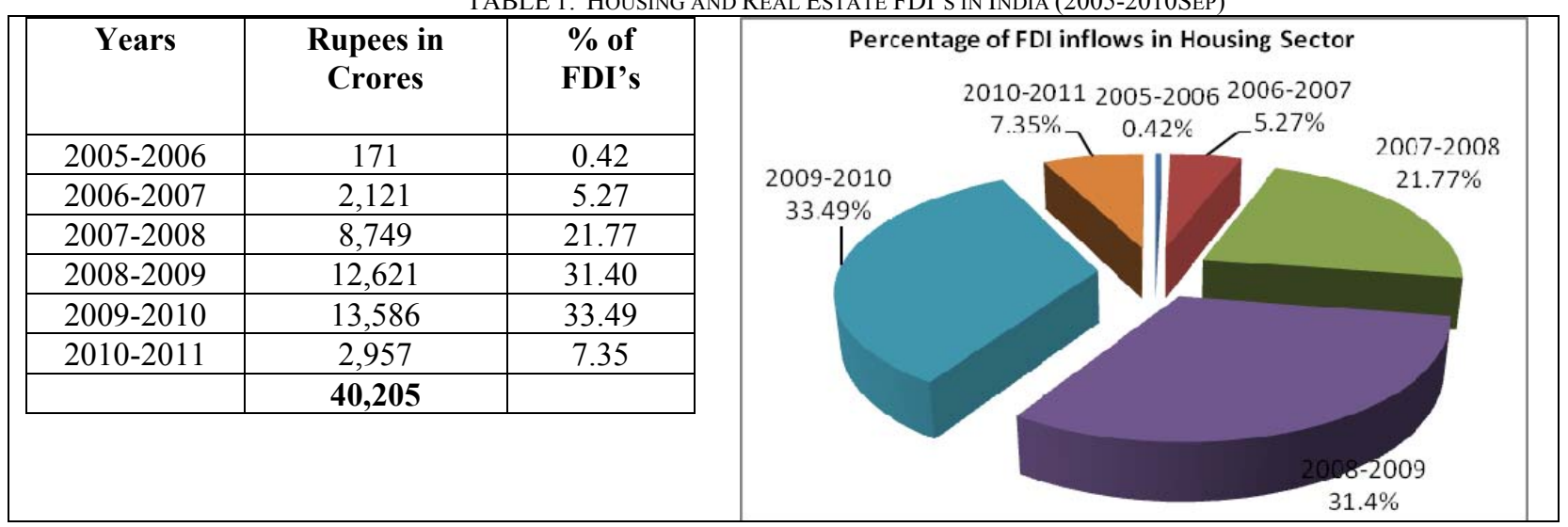

The above figures show that FDI's inflows in housing sector have increased from Rs171 crores in 2005-06 to Rs13, 586 crores in 2009-10. It indicates that FDI's inflows has jumped 80 times between 2005 and 2010.Even during the global recession period the realty sector in India has received a considerable amount of FDI's .But in 2010, FDI's to realty sector has come down to $7.35 \%$ till September. 
TABLE:2

FINANCIAL YEAR-WISE FDI INFLOWS DATA:

AS PER INTERNATIONAL BEST PRACTICES:

(Data on FDI have been revised since 2000-01 with expended coverage to approach International Best Practices)

(Amount USS million)

\begin{tabular}{|c|c|c|c|c|c|c|c|c|}
\hline \multirow{4}{*}{$\begin{array}{l}\text { S. } \\
\text { No. }\end{array}$} & \multirow{4}{*}{$\begin{array}{l}\text { Financial Year } \\
\text { (April-March) }\end{array}$} & \multicolumn{6}{|c|}{ FOREIGN DIRECT INVESTMENT (FDI) } & \multirow{4}{*}{$\begin{array}{r}\text { Investme } \\
\text { nt by } \\
\text { Fll's } \\
\text { Foreign } \\
\text { Institution } \\
\text { al } \\
\text { Investors } \\
\text { Fund } \\
\text { (net) }\end{array}$} \\
\hline & & \multicolumn{2}{|c|}{ Equity } & \multirow{3}{*}{$\begin{array}{l}\text { Re- } \\
\text { invested } \\
\text { earnings } \\
+ \\
\end{array}$} & \multirow{3}{*}{$\begin{array}{l}\text { Other } \\
\text { capital } \\
+\end{array}$} & \multirow{2}{*}{\multicolumn{2}{|c|}{$\begin{array}{c}\text { FDI FLOWS INTO } \\
\text { INDIA }\end{array}$}} & \\
\hline & & \multirow[b]{2}{*}{$\begin{array}{l}\text { FIPB } \\
\text { Route/ } \\
\text { RBl's } \\
\text { Automatic } \\
\text { Route/ } \\
\text { Acquisition } \\
\text { Route }\end{array}$} & \multirow{2}{*}{$\begin{array}{l}\text { Equity } \\
\text { capital of } \\
\text { unincorpor } \\
\text { ated } \\
\text { bodies \# }\end{array}$} & & & & & \\
\hline & & & & & & $\begin{array}{r}\frac{T o t a l}{F D I} \\
\text { Flows } \\
\end{array}$ & $\begin{array}{r}\text { \%age } \\
\text { growth } \\
\text { over } \\
\text { previous } \\
\text { year } \\
\text { (in USS } \\
\text { terms) }\end{array}$ & \\
\hline \multicolumn{9}{|c|}{ FINANCIAL YEARS $2000-2010$} \\
\hline 1. & $2000-01$ & 2,339 & 61 & 1,350 & 279 & 4,029 & 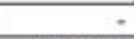 & 1,847 \\
\hline 2. & $2001-02$ & 3.904 & 191 & 1.645 & 390 & 6,130 & $(+) 52 \%$ & 1.505 \\
\hline 3. & $2002-03$ & 2.574 & 190 & 1.833 & 438 & 5.035 & $(-) 18 \%$ & 377 \\
\hline 4. & $2003-04$ & 2.197 & 32 & 1.460 & 633 & 4.322 & $(-) 14 \%$ & 10,918 \\
\hline 5 . & $2004-05$ & 3.250 & 528 & 1.904 & 369 & 6,051 & $(+) 40 \%$ & 8,686 \\
\hline 6. & $2005-06$ & 5,540 & 435 & 2.760 & 226 & 8,961 & $(+) 48 \%$ & 9,926 \\
\hline 7. & $2006-07$ & 15,585 & 896 & 5.828 & 517 & 22,826 & $(+) 146 \%$ & 3.225 \\
\hline 8. & $2007-08$ & 24,573 & 2,291 & 7.679 & 292 & 34,835 & $(+) 53 \%$ & 20,328 \\
\hline 9. & $2008-09(P)+$ & 27,329 & 666 & 6.428 & 757 & 35,180 & $(+) 01 \%$ & $(-\rightarrow) 15,017$ \\
\hline 10. & $2009-10(P)(+)(++)$ & 25.609 & 1,540 & 8.080 & 1.953 & 37,182 & $(+) 06 \%$ & 29,047 \\
\hline 11. & $2010-11$ (up to Aug. '10) & 8,887 & 219 & 2.166 & 118 & 11,390 & 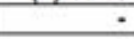 & 11,849 \\
\hline \multicolumn{2}{|c|}{$\begin{array}{l}\text { CUMULATIVE TOTAL } \\
\text { (from April '00 to August ' } 10 \text { ) }\end{array}$} & 121,787 & 7,049 & 41,133 & 5,972 & 175,941 & - & 82,691 \\
\hline
\end{tabular}

SOURCE: RBI's BULLETIN OCTOBER 2010 DT.12.10 .2010 (TABLE NO. 44 - FOREIGN INVESTMENT INFLOWS).

In the year 2005-06 the total inflows were $48 \%$ but during 2006-07 in has tremendously increased by $146 \%$, this was due to the implementation of $100 \%$ inflows policy which later in $2007-08$ has increased by $53 \%$ and in $2008-09$ by $1 \%$.

\section{A. Economic Growth with FDI in Housing in India}

India has been experiencing the impact of FDI's from a very recent period. Due to the government policy on FDI's, all real estate sectors, residential, commercial and retail are currently witnessing huge growth in demand. India, during the first half of 2005-06 fiscal has attracted more than three times foreign investment at US\$ 7.96 billion during making it amongst the "dominant host countries" for FDI's in Asia and the Pacific (APAC).After the initiatives of the government, the foreign investors have been more attracted in investing in India and so the construction activities have been enhanced. The real estate sector has been more organized in India since then and so improving competitive conditions for both the domestic and foreign investors. FDI's has helped the Indian economy grow, and the government continues to encourage more investments of this sort.

Foreign direct investment (FDI's) in India has played an important role in the development of the Indian economy. FDI's in India has - in a lot of ways - enabled India to achieve a certain degree of financial stability, growth and development. This money has allowed India to focus on the areas that may have needed economic attention, and address the various problems that continue to challenge the country. India has continually sought to attract FDI's from the world's major investors. FDI is permitted through financial collaborations, through private equity or preferential allotments, by way of capital markets through Euro issues, and in joint ventures. FDI is not permitted in the arms, nuclear, railway, coal \& lignite or mining industries.

TABLE 3: ECONOMIC GROWTH RATE IN INDIA (2003-2010)

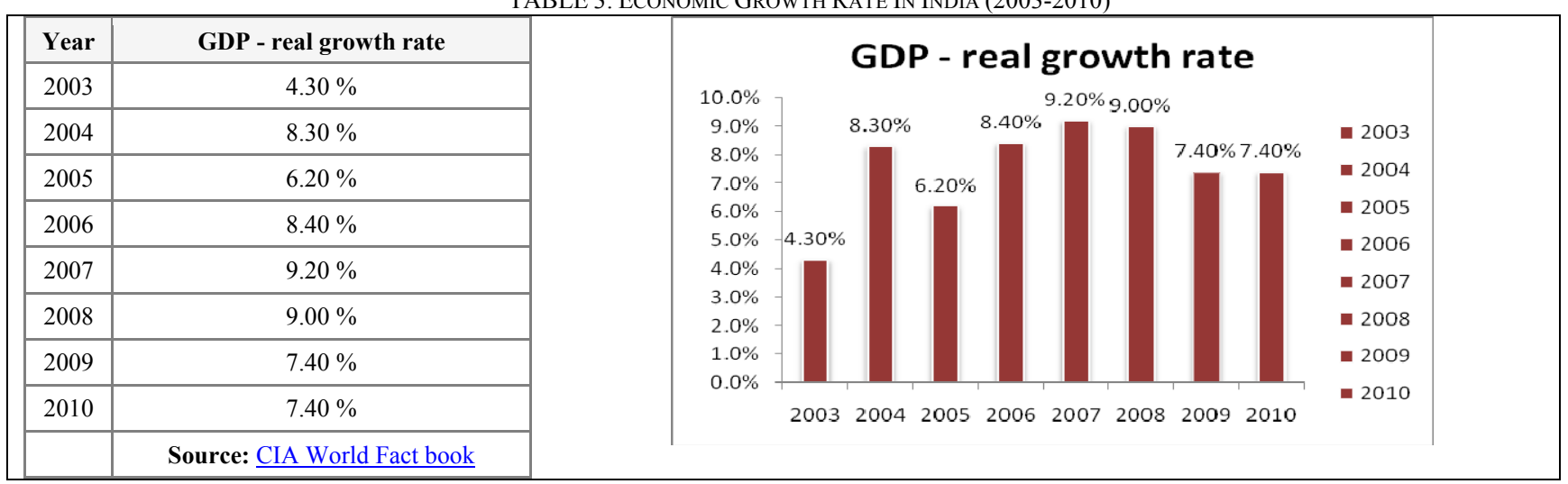




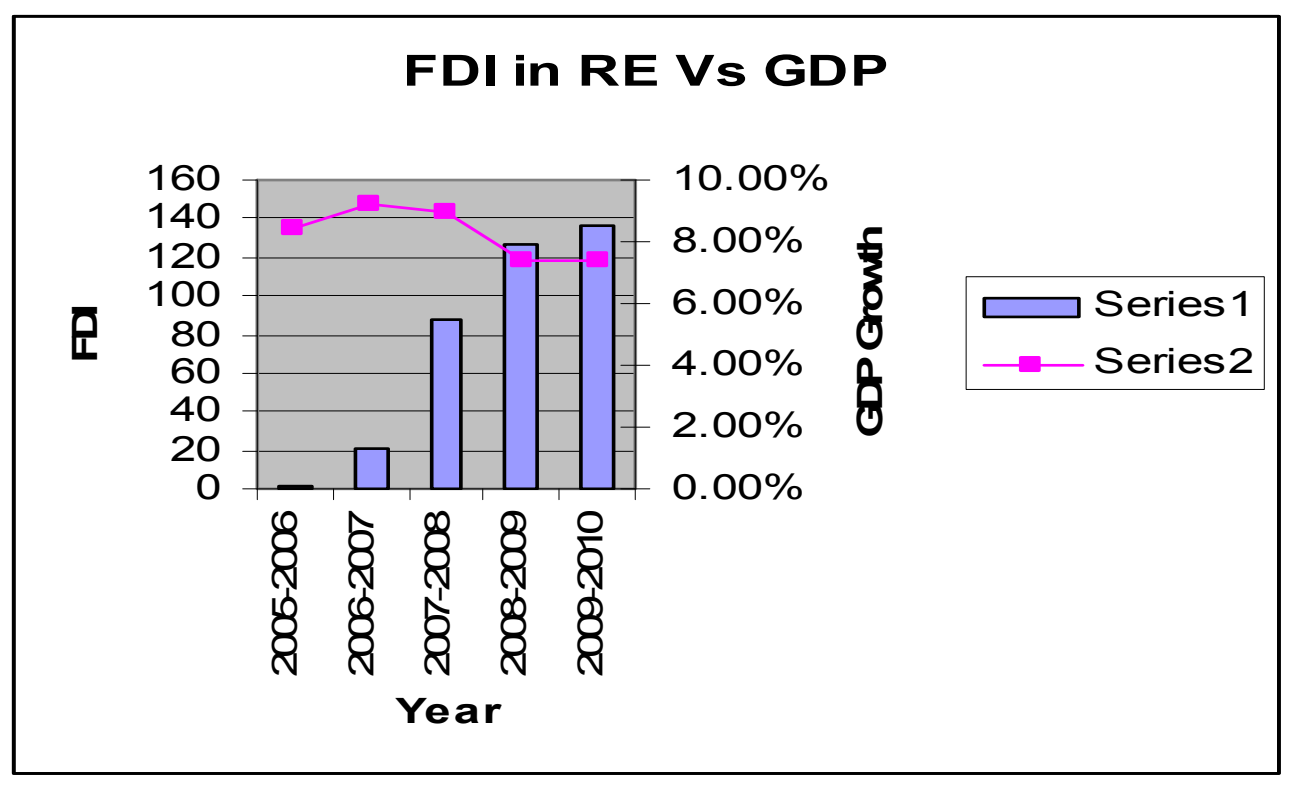

The above study highlights on the fact that the housing sector has received $21.77 \%$ in $2007-08$ which was just $5.27 \%$ in 2006. With the effect of permitting $100 \%$ FDI's, the inflows have increased to $31.90 \%$ in $2008-09$ and $33.49 \%$ in 2009-10 and so the GDP has also increased from 6.20 in 2005 to 8.40 in 2006 and 9.20 in 2007. This indicates that FDI's has positively contributed to the economic growth of India. Even thou there has been a negative correlation between the real estate sector and GDP but the housing have indirectly contributed to the economic growth.

TABLE:4 KaRL PEARSON's CORRELATION BETWEEN GDP \& REAL ESTATE

\begin{tabular}{|c|c|c|c|}
\hline & & $\begin{array}{c}\text { Housing \& } \\
\text { Real estate }\end{array}$ & GDP \\
\hline $\begin{array}{c}\text { Housing \& Real } \\
\text { estate }\end{array}$ & $\begin{array}{c}\text { Pearson } \\
\text { Correlation }\end{array}$ & 1.000 & -.378 \\
\hline & Sig. (2-tailed) & $\cdot$ & .460 \\
\hline GDP & $\mathrm{N}$ & 6 & 6 \\
\hline & $\begin{array}{c}\text { Pearson } \\
\text { Correlation }\end{array}$ & -.378 & 1.000 \\
\hline & Sig. (2-tailed) & .460 &. \\
\hline & $\mathrm{N}$ & 6 & 6 \\
\hline
\end{tabular}

The Karl Pearson's Correlation between GDP and FDI inflows in Housing indicates that the FDI inflows in Housing are increasing at an inverse proportion to the GDP growth rate with a pearson Correlation value of -.378 .

\section{B. Impact of Recession on FDI Inflows in India}

The global recession has changed the pattern of FDI flows with three major developing economies-Russia, Saudi Arab and India--becoming the top 10 largest recipients, creating history of sorts. An Assocham study reveals that China is leading as the priority host economy for FDIs among the developing economies and also the second largest FDI recipient in the world, followed by Hong Kong (4th), Russia (6th), Saudi Arabia (8th) and India (9th).

In 2007, total FDI inflow in the world soared to a record high of almost 2,100 billion dollars, of which developed countries received 1,444 billion dollars which is 68.8 per cent of the total FDI inflow in the world, while in the same year, developing and transition economies received only 31.2 per cent of the total inflow in the world.

In addition to other factors, increased screening requirements and new limitations of foreign equity policies of government during crisis is also impairing with the inflows. Even with the gradual recovery of FDIs in short term, developed nations chances of attracting more FDIs are fraught with mounting fiscal deficits and debt levels. Moreover, the global trends of economic growth are pointing to a stable and more rapid recovery for the developing and transition economies. The results of several business surveys also highlight an encouraging short-term review of FDI prospects in these economies. 
TABLE :5 TOTAL CUMMULATIVE FDI's INFLOWS IN INDIA FROM 2005-2010

\begin{tabular}{|l|l|}
\hline $\begin{array}{l}\text { Cumulative amount of } \\
\text { FDI's inflows }\end{array}$ & $\begin{array}{l}\text { AMOUNT } \\
\text { ( Crores) }\end{array}$ \\
\hline Upto2005 & $1,53,191.94$ \\
\hline Up to 2006 & $2,03,549$ \\
\hline Upto2007 & $2,83,284$ \\
\hline Upto2008 & $4,23,053$ \\
\hline Up to 2009 & $4,23,053$ \\
\hline Upto2010 (Till Sep) & $6,12,873$ \\
\hline Total & $\mathbf{2 0 , 9 9 , 0 0 3 . 9 4}$ \\
\hline $\begin{array}{l}\text { Source: RBI's Bulletin } \\
\text { www.rbi.ac.in }\end{array}$ & \\
\hline
\end{tabular}

\section{TOTAL CUMMULATIVE FDI INFLOWS}

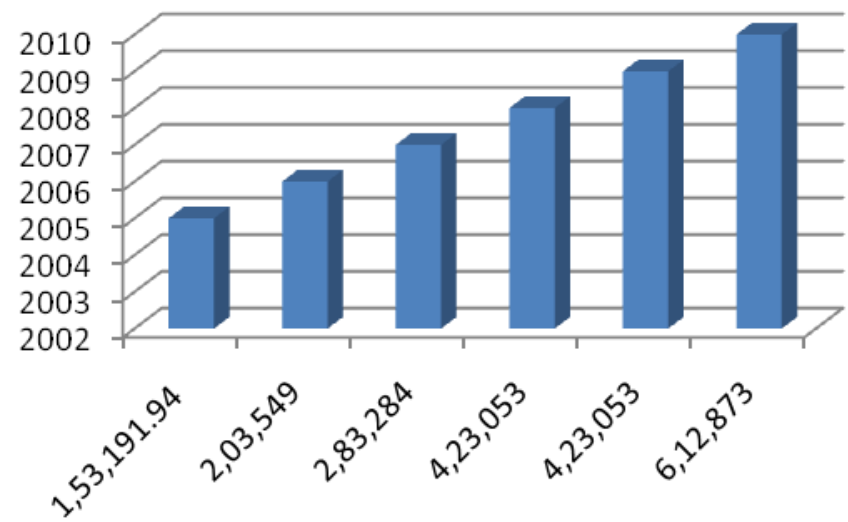

The study highlights that during 2007-2009 the FDI's inflows has almost doubled i.e. from Rs $2,83,284$ crores to Rs $4,23,053$ crores. This shows that India has been considered as the most attractive investment countries in Asia.
C. FDI Inflows in Housing in Comparison with Other Sectors

TABLE :6 SECTORS ATtRACTING HigheST FDI INFLOWS IN INDIA (FROM 2005 TO 2010 AUGUST)

\section{Amount Rupees in Crores}

\begin{tabular}{|c|c|c|c|c|c|c|c|c|c|}
\hline Rank & Sector & 2005-06 & 2006-07 & 2007-08 & 2008-09 & 2009-10 & 2010-11 & $\begin{array}{l}\text { Cummulative } \\
\text { FDI's inflows } \\
\text { (2000-2010 Aug) }\end{array}$ & Cum\% \\
\hline 1 & $\begin{array}{l}\text { Services Sector } \\
\text { (Financial-non Financial) }\end{array}$ & 2,339 & 21,047 & 26,589 & 28,516 & 20,776 & 9,506 & $1,11,023$ & 30.41 \\
\hline 2 & $\begin{array}{l}\text { Computer software \& } \\
\text { hardware }\end{array}$ & 6,172 & 11,786 & 5,623 & 7,327 & 4,535 & 2,438 & 45,937 & 12.58 \\
\hline 3 & $\begin{array}{l}\text { Telecommunications } \\
\text { (radio,paging,cellular } \\
\text { mobile,basic telephone } \\
\text { services) }\end{array}$ & 2,776 & 2,155 & 5,103 & 11,727 & 12,338 & 4,803 & 45,495 & 12.46 \\
\hline 4 & Constructions activities & 667 & 4,424 & 6,989 & 8,792 & 13,516 & 1,523 & 37,045 & 10.15 \\
\hline 5 & Housing \& Real estate & 171 & 2,121 & 8,749 & 12,621 & 13,586 & 2,957 & 39,861 & 10.92 \\
\hline 6 & Automobile Industry & 630 & 1,254 & 2,697 & 5,212 & 5,154 & 825 & 21,341 & 5.84 \\
\hline 7 & Power & 386 & 713 & 3,875 & 4,382 & 6,908 & 3,357 & 24,040 & 6.58 \\
\hline 8 & Metallurgical Industry & 6,540 & 7,866 & 4,686 & 4,157 & 1,935 & 4,170 & 16,247 & 4.45 \\
\hline 9 & Petroleum \&Natural gas & 64 & 401 & 5,729 & 1,931 & 1,328 & 2,403 & 12,491 & 3.42 \\
\hline 10 & $\begin{array}{l}\text { Chemicals } \\
\text { (other than Fertilizers) }\end{array}$ & 1,731 & 930 & 920 & 3,427 & 1,707 & 774 & 11,494 & 3.14 \\
\hline Total & & 21,536 & 52,697 & 70,960 & 88,094 & 81,730 & 32,756 & $3,64,974$ & $100 \%$ \\
\hline
\end{tabular}

Source: RBI's Bulletin www.rbi.ac.in

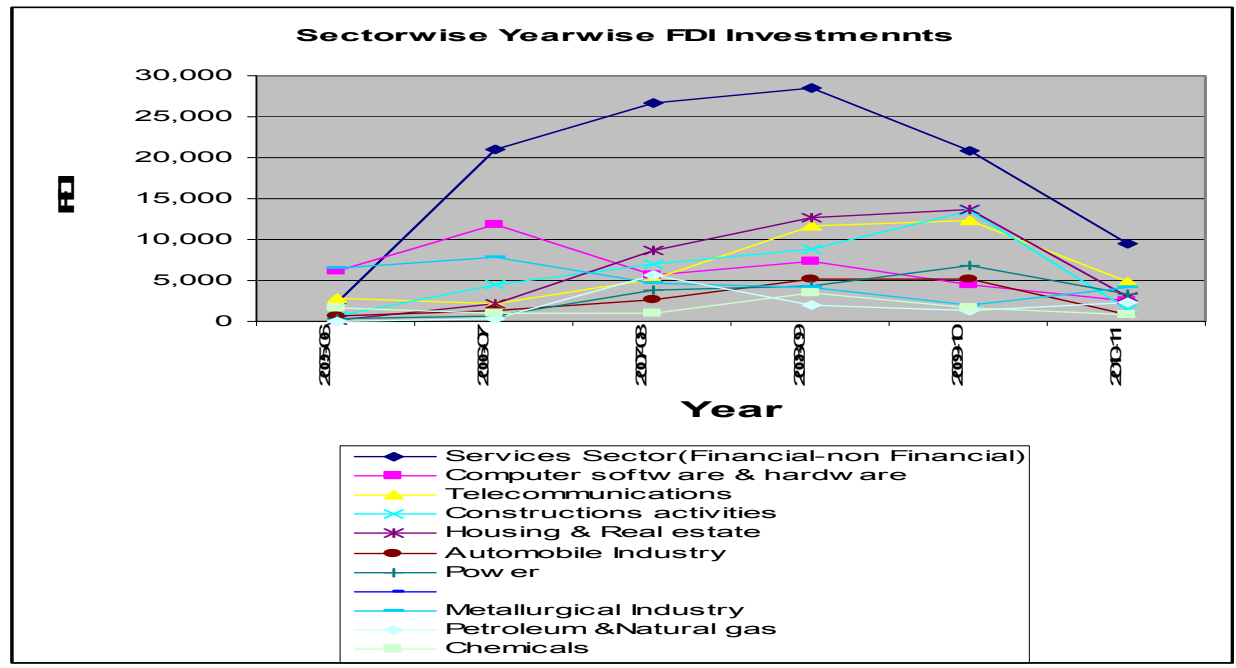


Amongst all the sectors, services sector has received the highest FDI till 2008 but later more FDI's have been pumped into the housing sector. This sector has witnessed the highest FDIs of Rs 13,586 crores in the year 2009-10. IL\&FS
Investment Managers (IIML) plans to invest US\$ 300 million, in real estate and urban infrastructure projects by the end of 2010.

\begin{tabular}{|c|c|c|c|c|c|c|c|}
\hline COUNTRY & 2005-06 & 2006-07 & 2007-08 & 2008-09 & 2009-10 & $\begin{array}{l}\text { Cumulative } \\
\text { Inflows (Apr '00 to } \\
\text { May '09) }\end{array}$ & $\begin{array}{l}\text { \%age to } \\
\text { total } \\
\text { Inflows } \\
\text { (in Rs.) }\end{array}$ \\
\hline MAURITIUS & 11,441 & 28,759 & 44,483 & 50,794 & 12,428 & 173,700 & $44 \%$ \\
\hline SINGAPORE & 1,218 & 2,662 & 12,319 & 15,727 & 1,280 & 35,132 & $9 \%$ \\
\hline U.S.A. & 2,210 & 3,861 & 4,377 & 8,002 & 852 & 28,811 & $7 \%$ \\
\hline U.K. & 1,164 & 8,389 & 4,690 & 3,840 & 306 & 23,210 & $6 \%$ \\
\hline NETHERLANDS & 340 & 2,905 & 2,780 & 3,922 & 540 & 16,392 & $4 \%$ \\
\hline JAPAN & 925 & 382 & 3,336 & 1,889 & 1,498 & 12,722 & $3 \%$ \\
\hline CYPRUS & 310 & 266 & 3,385 & 5,983 & 1,521 & 11,571 & $3 \%$ \\
\hline GERMANY & 1,345 & 540 & 2,075 & 2,750 & 999 & 10,488 & $3 \%$ \\
\hline FRANCE & 82 & 528 & 583 & 2,098 & 29 & 5,511 & $1 \%$ \\
\hline U.A.E. & 219 & 1,174 & 1,039 & 1,133 & 366 & 4,372 & $1 \%$ \\
\hline $\begin{array}{l}\text { TOTAL FDI's } \\
\text { INFLOWS * }\end{array}$ & 24,613 & 70,630 & 98,664 & 122,919 & 21,876 & 415,002 & \\
\hline
\end{tabular}

Source:DIPP, Federal Ministry of Commerce and Industry, Government of India

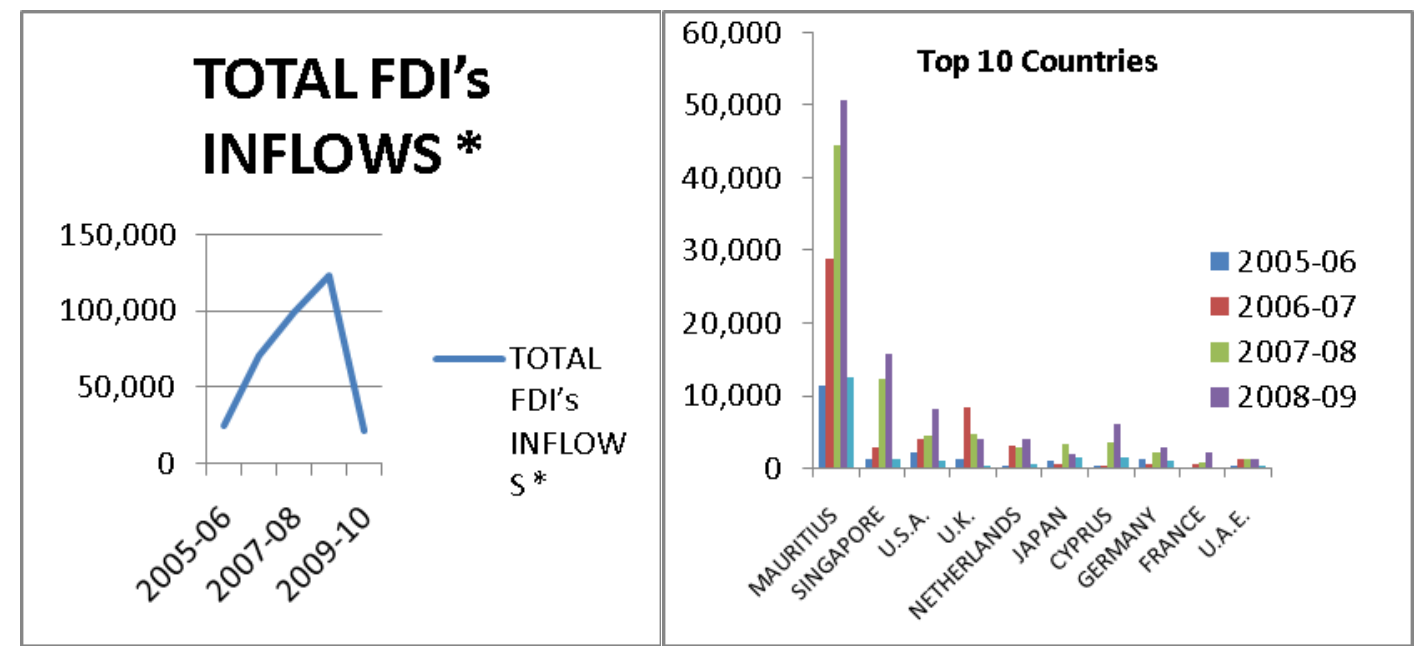

This table analyzes that Mauritius has contibuted $44 \%$ of the total FDI's inflows in India compared to other countires like US which was only $7 \%$ and UK 6\%. In May 2010, the government cleared 24 foreign investment proposals, worth US\$ 304.7 million. The government has allowed the Foreign Investment Promotion Board (FIPB), under the Ministry of Commerce and Industry, to clear FDI's proposals of up to US\$258.3 million. Earlier all project proposals that involved investment of above US\$ 129.2 million were put up before the Cabinet Committee of Economic Affairs (CCEA) for approval.

\section{CONCLUSION}

India has witnessed a steady growth in the economy with the FDI's inflows. Interestingly, given the booming property market across the country FDI's are not confined to metros and big cities alone. Thus since 2005, various real estate projects have been given a green signal by RBIs. But certain factors such as the economic conditions of the developing economies in the world are putting pressures on the recovery of FDI's flows.. The policy for FDI's have changed overtime with the changing requirements. India's share in the global FDI's regime is still minuscule which needs further liberalization in the policies.

\section{REFERENCES}

[1] Lata M Chakravarthy (2005) "Foreign Direct Investment in India", ICFAI University Press.

[2] Dr. Arabi. U, "Foreign Direct Investment(FDI's) Flows and sustained growth: A case study of India and China"

[3] Laura Alfaro, "Foreign Direct Investment and growth: Does the sector matter", Harvard Business School.

[4] Singh, Lakhwinder (2007), "India's economic growth and role of Foreign Direct Investment”

[5] T K Shandilya Anil Kumar Thakur (2008), "Foreign Direct Investment In India : Problems And Prospects”, Deep \& Deep Publications Pvt. Ltd, 1st Edition

[6] Suman Chatterjee (2009) “An Economic analysis of Foreign Direct Investment in India"

[7] Nirupa Bajpai \& Nandita Dasgupta CGSD (2004), "What constitutes Foreign Direct Investment? Comparsion of India and China" www.earth.columbia.edu

[8] Global recession has changed FDI's pattern, India high on priority, http://www.indianground.com/real estate FDI's.aspx

[9] RBI's Bulletin October $2010 \overline{\mathrm{dt}} \cdot 12.10 .2010$ (Table No. 44) FOREIGN INVESTMENT INFLOWS). 
International Journal of Trade, Economics and Finance, Vol.2, No.1, February, 2011

2010-023X

[10] www.indiahousing.com

[11] CIA World Fact book

[12] www.rbi.ac.in 